\title{
L'assurance des assurances
}

Hier

Aujourd'hui

Demain

Après-demain (ou hier soir)
Les caisses-maladies, plus exactement leurs parlementaires liges (cf. dictionnaire), ont exigé la suppression de l'obligation de contracter.

Elles réclament la suppression de la procédure d'approbation des primes par l'OFAS (Infosantésuisse, No 9, septembre 2001), car cette procédure "a pris malheureusement ces dernières années une tournure intolérable". Et l'éditorialiste de se plaindre des "allures arrogantes de certains représentants de l'autorité».

Les caisses-maladies exigeront la suppression de l'obligation d'assurer tous les malades! Comment voulez-vous faire des affaires avec des patients qui coûtent? Triste retour aux réserves, que la LAMal a si judicieusement exclues.

Les caisses achèteront des pharmacies, des hôpitaux; elles traiteront directement avec les grossistes, loueront les services de médecins blafards et vendront des tee-shirts.

Elles hésiteront peut-être quelques secondes à fonder leur propre chaîne de Pompes Funèbres.

Dr Claude Aubert, membre du CC de la FMH 